\title{
Strates
}

STRATES Matériaux pour la recherche en sciences sociales

2| 1987

Mélanges

\section{La bourgeoisie à Singapour}

Catherine Paix et Michèle Petit

\section{(2) OpenEdition}

\section{Journals}

Édition électronique

URL : http://journals.openedition.org/strates/344

DOI : $10.4000 /$ strates.344

ISSN : 1777-5442

Éditeur

Laboratoire Ladyss

Édition imprimée

Date de publication : 1 janvier 1987

ISSN : 0768-8067

Référence électronique

Catherine Paix et Michèle Petit, «La bourgeoisie à Singapour », Strates [En ligne], 2 | 1987, mis en ligne le 08 décembre 2004, consulté le 08 septembre 2020. URL : http://journals.openedition.org/strates/ 344 ; DOI : https://doi.org/10.4000/strates.344

Ce document a été généré automatiquement le 8 septembre 2020.

Tous droits réservés 


\section{La bourgeoisie à Singapour}

Catherine Paix et Michèle Petit 